\title{
Water consumption from hydropower plants - review of published estimates and an assessment of the concept
}

\author{
T. H. Bakken ${ }^{1,2}$, Å. Killingtveit ${ }^{1}$, K. Engeland ${ }^{2}$, K. Alfredsen ${ }^{1}$, and A. Harby ${ }^{2}$ \\ ${ }^{1}$ Norwegian University of Science and Technology, Department of Hydraulic and Environmental Engineering, \\ 7491 Trondheim, Norway \\ ${ }^{2}$ SINTEF Energy Research, 7465 Trondheim, Norway
}

Correspondence to: T. H. Bakken (tor.haakon.bakken@ sintef.no)

Received: 21 May 2013 - Published in Hydrol. Earth Syst. Sci. Discuss.: 24 June 2013

Revised: 23 August 2013 - Accepted: 5 September 2013 - Published: 15 October 2013

\begin{abstract}
Since the report from IPCC on renewable energy (IPCC, 2012) was published; more studies on water consumption from hydropower have become available. The newly published studies do not, however, contribute to a more consistent picture on what the "true" water consumption from hydropower plants is. The dominant calculation method is the gross evaporation from the reservoirs divided by the annual power production, which appears to be an oversimplistic calculation method that possibly produces a biased picture of the water consumption of hydropower plants. This review paper shows that the water footprint of hydropower is used synonymously with water consumption, based on gross evaporation rates.

This paper also documents and discusses several methodological problems when applying this simplified approach (gross evaporation divided by annual power production) for the estimation of water consumption from hydropower projects. A number of short-comings are identified, including the lack of clarity regarding the setting of proper system boundaries in space and time. The methodology of attributing the water losses to the various uses in multi-purpose reservoirs is not developed. Furthermore, a correct and fair methodology for handling water consumption in reservoirs based on natural lakes is needed, as it appears meaningless that all the evaporation losses from a close-to-natural lake should be attributed to the hydropower production. It also appears problematic that the concept is not related to the impact the water consumption will have on the local water resources, as high water consumption values might not be problematic per se. Finally, it appears to be a paradox that a reservoir might be accorded a very high water consumption/footprint
\end{abstract}

and still be the most feasible measure to improve the availability of water in a region. We argue that reservoirs are not always the problem; rather they may contribute to the solution of the problems of water scarcity. The authors consider that an improved conceptual framework is needed in order to calculate the water footprint from hydropower projects in a more reasonable way.

\section{Introduction}

Mitigating climate change requires the development of renewable energy sources in order to replace fossil-based energy. The IPCC Special Report on Renewable Energy (IPCC, 2012) was an important achievement and milestone in the assessment of the potential for renewable energy sources to replace fossil-based fuels. This report presents the most important renewable energy technologies and benchmarks them with respect to various criteria, including the needed volumes of water in the production of a certain volume of energy, assigned as "water consumption" of the benchmarked technology. This assessment reveals that in 2011 there was very limited number of publications that actually compared the water consumption of the different technologies on an equal basis. In addition, there were very few studies exclusively assessing the water consumption from hydropower production. Furthermore, there was a large spread in water consumption estimates for hydropower facilities in these studies and the values ranged from a minimum of $0.04 \mathrm{~m}^{3} \mathrm{MWh}^{-1}$ to a maximum of $209 \mathrm{~m}^{3} \mathrm{MWh}^{-1}$. The highest value is far beyond the other technologies which have maximum values typically 
in the range of $4-5 \mathrm{~m}^{3} \mathrm{MWh}^{-1}$. These findings caused great concern within the hydropower sector (IHA, 2011) as this might cause a reputational risk for the sector and also be a direct investment risk in new projects if hydropower is considered a "large-scale water consumer". This is especially when hydropower developments are planned in regions with limited freshwater resources. On the other hand, the hydropower sector stresses the need for the development of a conceptual framework for calculating the water consumption with common definitions and methodologies (IHA, 2011). This is because the current approach does not take the benefits of water storage into account (i.e., increased water availability) (IPCC, 2012), and hence might give a biased picture of the role of hydropower and water storage reservoirs in general. As a number of new studies have been carried out since the release of the IPCC (2012) report possibly filling out the fragmented picture, it is considered a suitable time to update the review by the IPCC.

It appears also opportune and adequate to ask the purpose of estimating the water consumption/water footprint. According to the water footprint manual (Hoekstra et al., 2011) the goal of assessing the water footprint is to analyze how human activities or specific products relate to issues of water scarcity and pollution. In addition, it was to study how activities and products can become more sustainable from a water perspective. The definition of the water footprint of a product is "the volume of freshwater used to produce the product, measured over the full supply chain" (Hoekstra et al., 2011).

The purpose of this study is

1. Review all published literature with respect to water consumption from hydropower plants, and present the range of estimates.

2. Document the methodological approaches used and evaluate the consistency in the methodology of estimating water consumption values.

3. Investigate trends in the published material, if any.

4. Discuss the present methodological approach when applied to hydropower projects and propose clarifications and/or refinements in order improve the precision of the methodology.

The basis for this study is a literature review that includes data from peer-reviewed and grey literature on the topic of water consumption from energy production in general and hydropower projects specifically. The literature has been compiled using traditional tools for scientific literature collection and direct contact with people and institutions involved in the on-going debate. It should be underlined that all the used material is available from open, public sources. The published data and information was extracted from the publications and reformatted for the purpose of this study. The calculation methods applied are presented, as well as the geographical extent of the estimates, ranging from single-plant estimates to global averages. Second, the single-plant data set compiled from the published literature is diversified with respect to a set of factors such as calculation method and climatic region in order to uncover trends in the compiled data set. Third, the present and dominating methodology of estimating water consumption is discussed with respect to the specifics of hydropower technology. As this paper is accompanied by a set of examples demonstrating aspects of the methodology that needs to be clarified, our paper should provide useful input for an improved conceptual framework.

\section{Overview of published literature and estimates}

\subsection{Terms and definitions used in the context of water consumption}

The review of relevant literature on water consumption and hydropower production did not reveal a consistent and agreed set of terms and definitions. Terms like water consumption, water losses, water withdrawal and water footprint seem to have slightly different meanings determined by the context and are applied in an inconsistent manner in a number of relevant publications (Hutson et al., 2004; Kenny et al., 2009; Fthenakis and Kim, 2010; Macknick et al., 2012b; Pfister et al., 2011; Hoekstra et al., 2011).

In this paper we have defined water consumption in hydropower production as the quantity of water that leaves the analyzed system, and can hence be considered lost for hydropower production and the downstream water users/ecosystem. In the most relevant publications, i.e., those presented in Table 1 and listed earlier in this paragraph, "the system" is interpreted as being the reservoir that is directly linked to the hydropower plant. According to the Water Footprint Manual (Hoekstra et al., 2011), "consumption" refers to loss of water from the available ground- and surface water body in a catchment area. Losses occur when water evaporates, returns to another catchment, the sea or is incorporated into a product.

Following the calculation-method used in Mekonnen and Hoekstra (2012), the "water footprint of hydropower" is identical to the "water consumption of hydropower" (in the understanding gross annual evaporation divided by the annual power production) as used in the majority of the reviewed publications, and is hence used synonymously in this paper.

As seen in Table 1, the use of gross evaporation (divided by the annual production) (Eq. 1) is the dominating calculation method for the published estimates of water consumption from hydropower plants. This approach does not take into account the evaporation losses prior to construction of the hydropower plant. Also, the reservoir could originally have been a natural lake or terrestrial area inundated due to the 
establishment of the reservoir. The "net" calculation method (Eq. 2) subtracts evaporation rates from the reservoir surface by the evaporation rates prior to the hydropower development divided by annual power production:

Gross water consumption $=\frac{\text { Evaporation reservoir }}{\text { Annual powerproduction }}$
Net water consumption $=\frac{\text { Evaporation reservoir }- \text { Evaporation before inundation }}{\text { Annual power production }}$

Furthermore, a third approach ("water balance") for the calculation of water consumption from hydropower plants is proposed by Herath et al. (2010). This is defined as follows:

Water balance $=\frac{\text { Evaporation reservoir }- \text { Direct rainfall reservoir }}{\text { Annual power production }}$.

Even though the definition of water consumption does not exclude other loss terms from being part of the water loss, it appears from the reviewed publications that the dominating term for water losses is evaporation losses from the reservoir surface. The importance of seepage as a loss term has been discussed (e.g., Gleick, 1994), but it is argued that this is in most cases very small and if present will return the water back to the river basin and therefore should not be considered "lost" water.

Finally, it should be mentioned that the given water consumption estimates (as in Eqs. 1-3) are specific water consumption rates, expressed per unit of power production, and not absolute water consumption. The specific water consumption estimates must be multiplied by the power production in the specific case in order to indicate how much water is "lost" to the atmosphere due to evaporation.

\subsection{Available publications and their range in estimates (primary sources)}

Table 1 presents the primary sources of water consumption estimates. Readers should note that some of the estimates presented in Table 1 are based on different calculation methods (gross, net and water balance), with gross evaporation divided on annual production as the dominating method. In most cases, the three different calculation methods give such different estimates that they cannot be compared directly without a clear understanding of the intrinsic assumptions of the methods. This is discussed further in Sect. 3.1.

Furthermore, the compiled estimates include hydropower plants where the reservoirs have a primary purpose that is different than hydropower generation (e.g., reservoirs to supply irrigation systems with water in dry periods). Despite this, the water losses are in all cases, except one (M. J. Pasqualetti and S. Kelly, personal communication, 2008), allocated to the hydropower production even though the reservoir might facilitate two or more purposes and no defined methodology for allocation of the losses is available. Some of the plants in the reviewed studies are also built with reservoirs utilizing existing lakes for water storage, possibly adding only some minor regulation to the existing, natural variation in order to use the storage capabilities more efficiently. The "reservoir" would hence introduce a very limited change to a possibly very large and close to pristine water body, and the water losses attributed to the hydropower production might appear very large compared to the change introduced by the hydropower plant. These issues are discussed further in Sect. 3.5.

The estimates provided in Table 1 vary considerably in their spatial extent, from estimates valid for one specific (single) plant as, for example, Herath et al. (2011), via estimates given as average values for a region (e.g., one US State as for instance given by Gleick, 1992) to a global average as provided by Gerbens-Leenes et al. (2009). This means that the estimates are not applicable for use on all scales and support different types of decision-making. The global values should hence be used as an indication for global water losses from hydropower plants, and should not be downscaled to express the water consumption from an individual plant. Conversely, the results from one specific plant must be considered specific for the analyzed plant only. It should added that the system boundary of the estimates of the global average still might be the reservoirs of the plants used in the calculation of the global average. The issue of setting the spatial and temporal system boundaries are discussed in Sect. 3.2.

Despite the reservations and limitations given above, it is interesting to see that some of the newly published data (e.g., Mekonnen and Hoekstra, 2012; Tefferi, 2012; and Demeke et al., 2013) are far beyond the earlier published estimates on hydropower by IPCC (2012). Compared with other renewable technologies, this makes the water consumption from hydropower plants enormous, as the other renewables (and non-renewables) are up to a maximum of approx. $5 \mathrm{~m}^{3} \mathrm{MWh}^{-1}$ (IPCC, 2012). This makes it also pertinent to study the methodological approach and its relevance to hydropower.

In addition to the primary sources listed in Table 1, a number of publications are considered relevant to this topic and should be mentioned, such as US Department of Energy (2006), Fthenakis and Kim (2010), Macknick et al. (2011, 2012a), Pfister et al. (2011) and IPCC (2012). The IPPC Special Report on Renewable Energy Sources (IPCC, 2012) is definitely the most acclaimed of these publications and uses the following sources as documentation for their estimates of water consumption from hydropower; Gleick (1993), Torcellini et al. (2003), Mielke et al. (2010), Fthenakis and Kim (2010), indicating that until recently there was extensive re-use of the geographically very limited data set published by Gleick (1993). The water consumption estimates presented in IPCC (2012) ranged from a minimum of $0.04 \mathrm{~m}^{3} \mathrm{MWh}^{-1}$ to a maximum of $209 \mathrm{~m}^{3} \mathrm{MWh}^{-1}$. This range in values is based on very few data points $(n=2)$ from 4 sources: Gleick (1993), LeCornu (1998), Torcellini et al. (2003) and Mielke et al. (2010). From our review of recent publications, it is clear that there are now more publications available than when the IPCC report was 


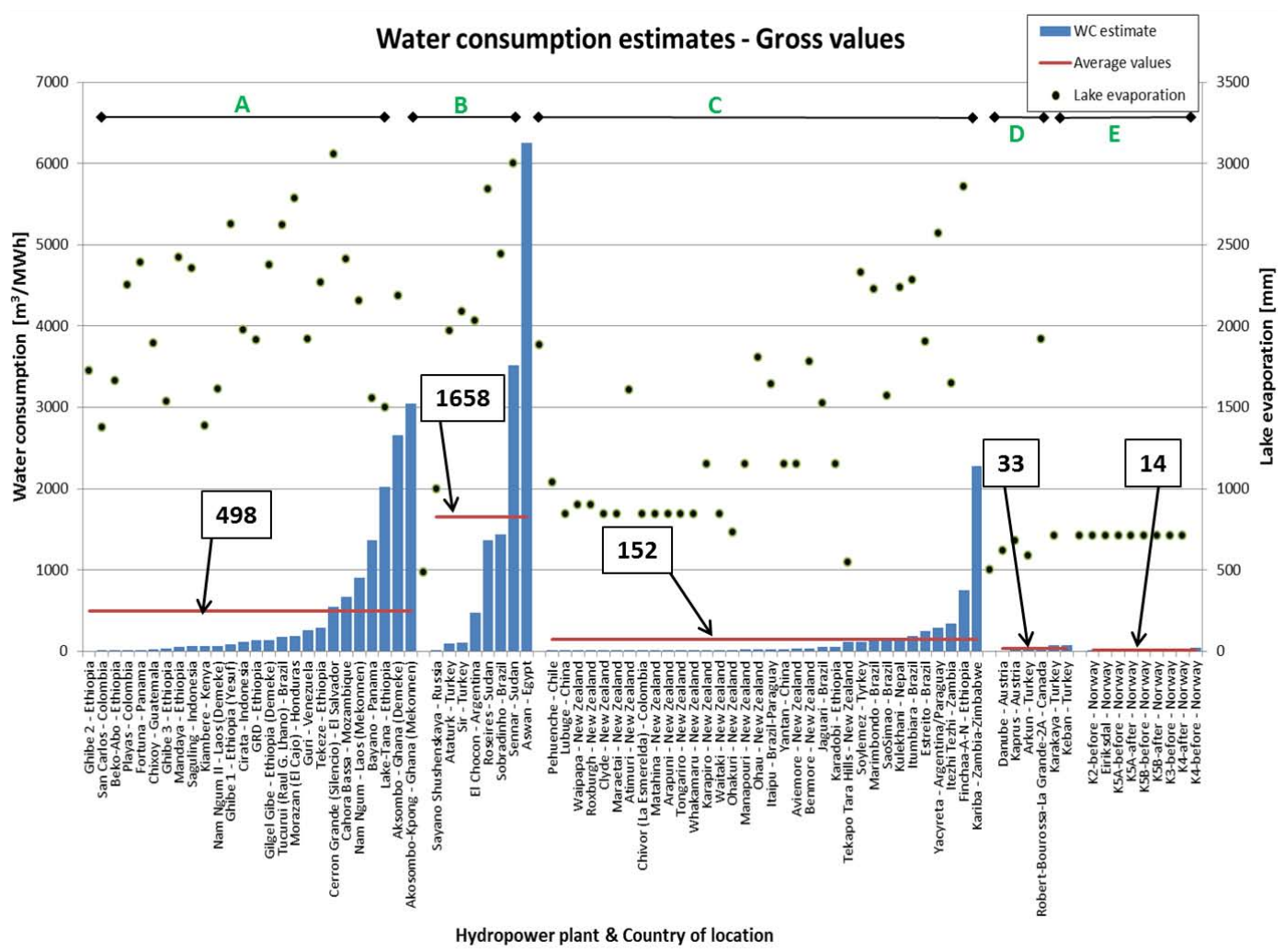

Fig. 1. The figure presents gross water consumption estimates and evaporation rates for the individual plants. The horizontal lines with number tags attached are average water consumption (arithmetic averages) values for the climate zones according to the classification given by Köppen-Geiger (Köppen, 1936). The codes of the 5 climate zones are given in red. The "before" and "after" annotation to the Norwegian data refers to before and after refurbishment of the hydropower system.
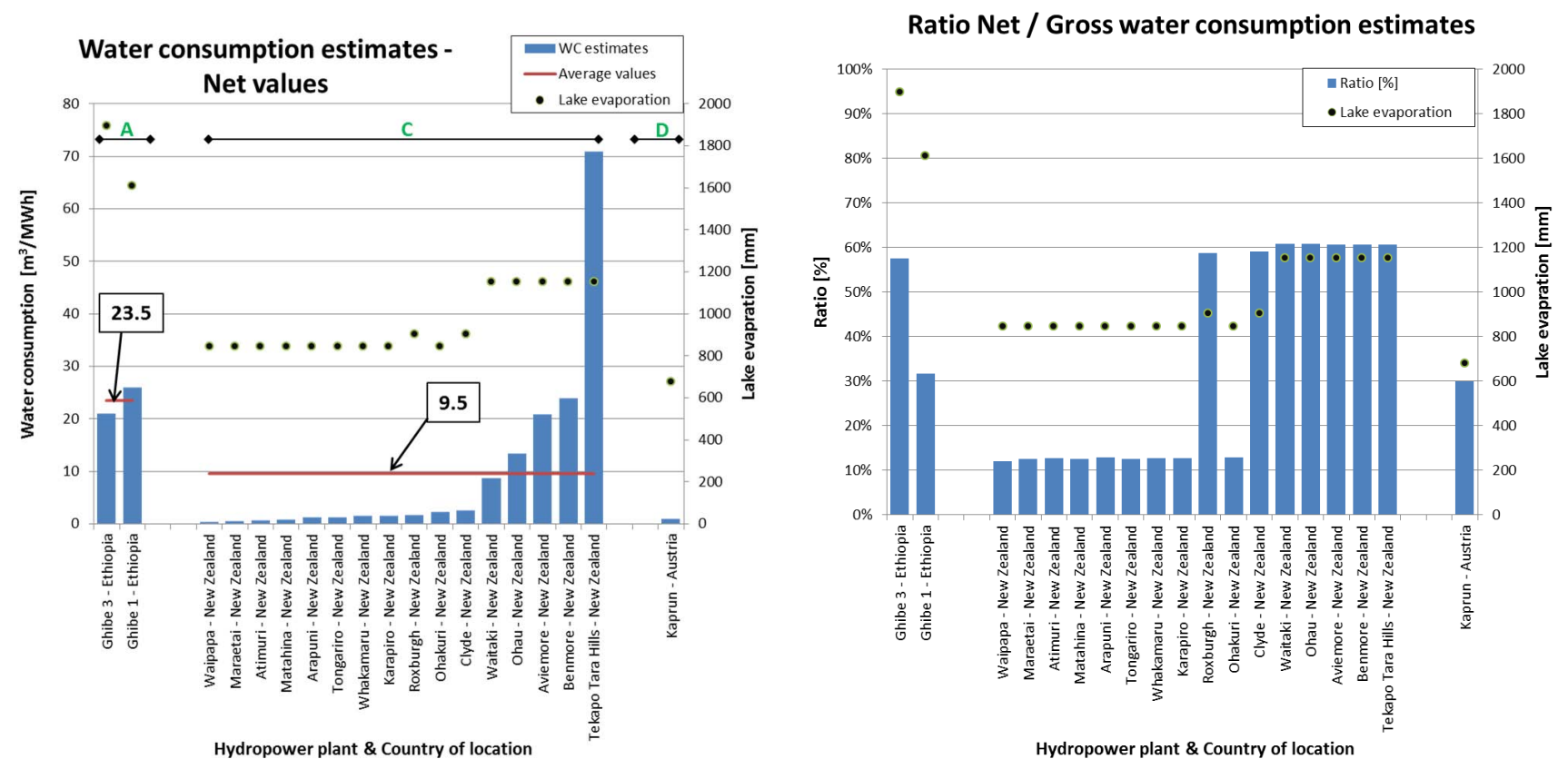

Fig. 2. The left panel of the figure presents net water consumption estimates and evaporation rates for individual plants. The number tags are arithmetic averages of water consumption. The right panel presents the differences (ratio net/gross, given in \%) in water consumption rates for those individual plants with both net and gross water consumption estimates. 
written, contributing to a better understanding of the performance of hydropower in the context of water consumption.

It should finally be noted that the quality of the reviewed studies might vary considerable, as the list of publications range from master's theses and technical reports to peerreviewed scientific articles.

\subsection{Data sources providing single-plants estimates}

The primary data presented in Table 1 are either a range of estimates providing minimum, average and the maximum values for a number of single-plant studies or estimates providing spatial aggregated estimates for water consumption, for example, average estimates for the region California (Gleick, 1992) or a world-wide average (Gerbens-Leenes et al., 2009). Despite this, some of the given publications are based on water consumption estimates from single-plants and these data are also available from the publications. It would hence be interesting to compile these single-plants data together in order to try to explain why some of the estimates are very high or very low and try to detect any trends in the material. A further analysis of the complied data set will also be interesting in terms of improving the methodology for estimating water consumption values for hydropower plants.

The main data sources providing single-plant estimated with identifiable plants are Herath et al. (2011), Mekonnen and Hoekstra (2012), Arnøy (2012), Yesuf (2012), Tefferi (2012) and Demeke et al. (2013). In the following, these data sources are merged and represent the compiled data set that was used in the analysis. The data sets were used directly with their given water consumption values, except for units conversions into $\mathrm{m}^{3} \mathrm{MWh}^{-1}$, in order to harmonize the compiled data set. Some of the data were supplemented with additional properties, for example, which climatic region the plants are located, in order to reveal some of the differences in the data estimates. The Köppen-Geiger classification method (Köppen, 1936) was used for the climatic regions. This system takes into account vegetation, temperature and precipitation and divides climates into 5 main categories, with a number of sub-groups within each of these categories. The gross values sorted by climatic zones are presented in Fig. 1, while the net values are presented in the left-hand side of Fig. 2.

The 3 studies by Herath et al. (2011), Yesuf (2012) and Demeke et al. (2013) present estimates for both gross and net water consumption rates. In these cases the inundated areas are assumed to be covered with pasture (Herath et al., 2011) and agricultural and grazing areas (Yesuf, 2012) prior to inundation, while Demeke et al. (2013) gives no information. The difference in water consumption values between the net and gross calculation approaches is hence determined by the land use/cover prior to inundation (Fig. 2, right panel).

Looking into the presented data on gross water consumption rates (Fig. 1), it is clear that there are both low and very high rates for all the three climatic zones $\mathrm{A}, \mathrm{B}$ and $\mathrm{C}$.
Climatic zones A and B especially show well-distributed data between the minimum and the maximum data, while $\mathrm{C}$ has basically only one sample providing a high estimate, which is the Kariba Dam on the border between Zambia and Zimbabwe. The reason why Kariba Dam comes out with such a high value is the combination of a very large surface area and high evaporation rate compared to the other plants in climatic zone $\mathrm{C}$. The climatic zones $\mathrm{D}$ and $\mathrm{E}$ have generally lower water consumption rates than $\mathrm{A}, \mathrm{B}$ and $\mathrm{C}$, which is indicated by their average values. The maximum value in the entire data set is the Aswan Dam in Egypt with a water consumption estimate of $6250 \mathrm{~m}^{3} \mathrm{MWh}^{-1}$.

The data set consisting of the net water consumption estimates (Fig. 2, left panel) is much smaller than the data set of gross values (only 3 studies), and contains values that are much lower. The average net and gross water consumption values for climate A are 23.5 and $518 \mathrm{~m}^{3} \mathrm{MWh}^{-1}$, respectively, and for climate $\mathrm{C} 152$ and $9.5 \mathrm{~m}^{3} \mathrm{MWh}^{-1}$. In these cases the net estimates were in the range of approx. 12$60 \%$ of the gross estimates. The difference in (arithmetic) average values between climate zone A and C (23.5 and $9.5 \mathrm{~m}^{3} \mathrm{MWh}^{-1}$, respectively) is very small for the net values compared to the similar difference for the gross values (498 and $152 \mathrm{~m}^{3} \mathrm{MWh}^{-1}$, respectively).

Some of the extremes and large values can possibly be explained by the fact that their reservoirs have a very large surface area. Mekonnen and Hoekstra (2012) have found that there is a relation between surface area of the reservoir and the water consumption estimates. This is, of course, not surprising as the numerator of Eqs. (1) and (2) is the product of the specific evaporation rates (gross or net per unit area) and the total surface area, and hence is very sensitive to evaporation rates. The reason for having a large surface area is, however, not exclusively due to the hydropower production, as the origin of the reservoir might be a large natural lake and that the multi-purpose function of the reservoir makes it larger than needed for hydropower production exclusively, which is also noted in the data set by Demeke et al. (2013) holding numerous multi-purpose reservoirs. The power production thus could not be determined directly by the surface area.

The fact that the dominating calculation method for water consumption values is very simplistic could also lead to individual differences being masked out. This means that the calculation method niether takes into account the specifics of the individual plants/reservoirs nor the group of plants that are regulated together, for instance in a cascade. Furthermore, the calculation method does not distinguish between natural lakes used as reservoir that could have a surface that is much larger than needed for the purpose of the hydropower production nor have a clear methodology to "share the burden of the water consumption" between the various interests benefitting from the reservoir. Only one study (M. J. Pasqualetti and S. Kelly, peronsal, communication, 2008) attempts to assign water losses between the water uses in a multi-purpose 
Table 1. The primary sources of water consumption estimates (adapted from Bakken et al., 2013a). In order to facilitate the comparison, the estimates are all converted into $\mathrm{m}^{3} \mathrm{MWh}^{-1}$ from their original publications. All the publications and estimates are from primary data sources only.

\begin{tabular}{|c|c|c|c|}
\hline Study & Estimate $\left[\mathrm{m}^{3} \mathrm{MWh}^{-1}\right]$ & Geographical region & Calculation method \\
\hline Gleick $(1992,1993)$ & $\begin{array}{l}0.04(\min ) \\
5.4(\text { median }) \\
209(\max )\end{array}$ & $\begin{array}{l}\text { California, USA (a diverse set of } \\
100 \text { plants) }\end{array}$ & Eq. (1) (gross) \\
\hline Gleick (1994) & $\begin{array}{l}\text { Mean: } 5.4 \mathrm{~m}^{3} \mathrm{MWh}^{-1} \\
\text { Median: } 26 \mathrm{~m}^{3} \mathrm{MWh}^{-1} \\
\text { Average: } 17 \mathrm{~m}^{3} \mathrm{MWh}^{-1}\end{array}$ & $\begin{array}{l}\text { California } \\
\text { US averages }\end{array}$ & Eq. (1) (gross) \\
\hline $\begin{array}{l}\text { Torcellini et al. } \\
(2003)\end{array}$ & 68 (average) & $\begin{array}{l}\text { US average }-120 \text { largest plants, } \\
\text { providing } \sim 65 \% \text { of prod. in } 1999\end{array}$ & Eq. (1) (gross) ${ }^{\mathrm{a}}$ \\
\hline $\begin{array}{l}\text { Pasqualetti and } \\
\text { Kelly (2008) }\end{array}$ & 113.9 & Arizona, USA & Eq. (1) (gross) $)^{b}$ \\
\hline $\begin{array}{l}\text { Gerbens-Leenes et } \\
\text { al. (2009) }\end{array}$ & 80 & Global average $\mathrm{c}^{\mathrm{c}}$ & Eq. (1) (gross) \\
\hline Herath et al. (2011) & $\begin{array}{l}21.8 \text { (gross average) } \\
9.8 \text { (net average) } \\
5.6 \text { (water balance) }\end{array}$ & $\begin{array}{l}\text { "All plants" Northern and } \\
\text { Southern New Zealand }\end{array}$ & $\begin{array}{l}\text { Eq. (1) (gross), Eq. (2) (net) and } \\
\text { Eq. (3) (water balance) })^{\mathrm{d}}\end{array}$ \\
\hline $\begin{array}{l}\text { Mekonnen and } \\
\text { Hoekstra (2012) }\end{array}$ & $\begin{array}{l}1.08(\min ) \\
244.8 \text { (average) } \\
3045.6(\max )\end{array}$ & $\begin{array}{l}\text { World-wide, } 35 \text { plants, } \sim 8 \% \text { of } \\
\text { global installed capacity }\end{array}$ & Eq. (1) (gross) \\
\hline Arnøy (2012) & $\begin{array}{l}3.8-4.4 \text { (range Gross E) } \\
-87.7 \text { to }-3.1 \text { (range WB) }\end{array}$ & Norway & Eqs. (1) and (3) (water balance) \\
\hline Yesuf (2012) & $\begin{array}{l}34 \text { (gross } \min ) \\
82 \text { (gross } \max ) \\
10(\text { net } \min ) \\
26(\text { net } \max )\end{array}$ & 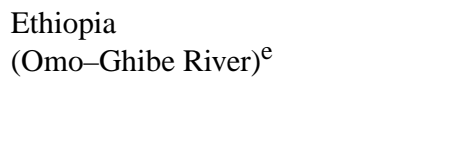 & Eq. (1) (gross) and Eq. (2) (net) \\
\hline Tefferi $(2012)^{f}$ & $\begin{array}{l}11(\min ) \\
136.9(\max ) \\
99(\text { w. average }) \\
1371(\min ) \\
3521(\max ) \\
1480 \text { (w. average) }\end{array}$ & $\begin{array}{l}\text { Ethiopia (Blue Nile) } \\
\text { Sudan (Blue Nile) } \\
\text { Roseires and Sennar } \\
\text { Irrigation reservoirs }\end{array}$ & Eq. (1) (gross) \\
\hline Demeke et al. (2013) & $\begin{array}{l}0(\min ) \\
6250(\max )\end{array}$ & $\begin{array}{l}\text { Austria, Ethiopia, Turkey, Ghana, } \\
\text { Egypt and PDR Lao }\end{array}$ & Eq. (1) (gross) and Eq. (2) (net) \\
\hline
\end{tabular}

\footnotetext{
a The study also includes an assessment of the evaporation prior to damming, assuming a free-flowing river. Estimates of evaporation before are only $3.2 \%$ of the evaporation after damming, giving a negligible difference between gross and net evaporation. ${ }^{\mathrm{b}}$ This study takes into account the multi-purpose functions of the reservoirs, and the water consumption is assigned to the various water users based on the economic valuation of water to each sector/user. In this study, $55 \%$ of the losses were assigned to hydropower. ${ }^{\mathrm{c}}$ This study combines global hydropower production (Gleick, 1993) with global evaporation estimates from reservoirs (Shiklomanov, 2000). ${ }^{\mathrm{d}}$ The net water balance method is defined as the evaporation from the reservoir surface minus the direct rainfall on the reservoir, divided by production. ${ }^{\mathrm{e}}$ The results are based on the assessment of the built Ghibe I and II and Ghibe III, which is currently under construction. ${ }^{\mathrm{f}}$ This study includes a large lake/reservoir where irrigation is the most dominating water use, and also a large lake where hydropower is just a minor add-on, giving high water consumption estimates as all the evaporation losses are attributed to the hydropower production.
}

reservoir. This is done by attributing the losses according to the water value of the various uses.

It is difficult to understand the relevance of the water footprint calculations as defined by Herath et al. (2011) (Eq. 3) and applied by Arnøy (2012). The calculation method simply indicates if the evaporation is larger than the precipitation on the reservoir surface, divided by the power production. The values for the individual plants (not presented in this paper) vary from $-87.7 \mathrm{~m}^{3} \mathrm{MWh}^{-1}$ as the lowest to the $70.2 \mathrm{~m}^{3} \mathrm{MWh}^{-1}$ as the highest, while the majority of the estimates (17 out of 25) are in the range of -10 to $10 \mathrm{~m}^{3} \mathrm{MWh}^{-1}$. From hydrological statistics of 
Norway (Beldring et al., 2002) it can easily be seen that the rainfall is basically much greater than the evaporation all over Norway, giving a negative water footprint if calculated according to the water balance approach (Eq. 3) at most locations. This also appears to be in conflict with the water footprint concept (Hoekstra et al., 2011), which should give numbers ranging from zero to infinite positive.

From the review of the published estimates and the methodology for calculating water consumption of hydropower plants, the methodology generally appears oversimplistic and imprecise in order to calculate reasonable and justifiable numbers for hydropower and omits several important features of reservoirs such as cascaded development of plants, multi-purpose use and establishment of reservoirs based on natural lakes. The reason why we argue this is further explored in the following section, accompanied by calculation examples demonstrating the wide range of outcomes given by the lack of a clear methodology.

\section{Discussion}

\subsection{The problem of inconsistency in the calculation method}

As described first in Sect. 2.1 there are basically three different methods for calculating the water consumption from hydropower plants. Among these, the gross water consumption is the dominating and the only method applied and published up to 2010, where the net water consumption and the water balance approach were introduced by Herath et al. (2011). The publication by Mekonnen and Hoekstra (2012), being among the strong proponents of the water footprint methodology (Hoekstra et al., 2011) claims that the gross water consumption approach is the correct way of applying the water footprint methodology on hydropower. The net approach differs from gross approach as it takes into account the evaporation losses from an area prior to the development of the hydropower plant. The water balance approach is the third method that corrects the evaporation losses by the direct rainfall to the reservoir surface. This method has been commented on before (see Sect. 2.3), and we find the usefulness of this approach limited.

The use of the gross evaporation as the basis is controversial as even a small hydropower plant making use of very limited water from a large lake will be attributed a large water consumption/footprint, but literally causing no change in the water balance. Similarly, in the case of inundation of "water hungry" vegetation, the evaporation from the flooded areas will to a limited extent change the original evaporation. There are also published studies indicating that natural vegetation could have as high evaporation rates as from lakes (Leigh Jr., 1999). On the other extreme, the establishment of a reservoir in a desert area (e.g., Aswan Dam on the border of Egypt/Sudan) will cause a net loss of water as the evaporation prior to the damming is very limited. The gross methodology does not differentiate between these cases and the calculated water consumption will be the same no matter if the area use prior to inundation by the reservoir was a lake or swamp-land on one hand or a desert on the other. Furthermore, if the spatial boundaries are set beyond the extent of the reservoir, indirect effects on land and water use introduced by the establishment of the reservoir should be accounted for. Estimating the water consumption would in this case become much more demanding, especially if the net effect is analyzed.

According to Hoekstra et al. (2011) and Mekonnen and Hoekstra (2012) the gross evaporation should be used as the basis for calculating the water footprint of hydropower as "the water footprint is not meant to refer to additional evaporation (compared to some reference situation), but for quantifying the volume of water consumption that can be associated with a specific human purpose". Despite this, it appears strange to us if an activity is attributed an enormous loss of water (as could be the case with the gross water consumption) without changing the water balance from pristine areas, and we believe that a different approach should be selected to assess the water consumption from hydropower, that is, the net water consumption or any other improved conceptual method, which is also supported by Demeke et al. (2013).

\subsection{Setting the system boundaries}

It has been identified in numerous LCA studies that the issue of setting the system boundaries might have a large effect on the outcome of the study (e.g., Raynolds et al., 2000 and Modahl et al., 2013). This is also the case for water consumption from hydropower projects and is discussed in the following section. The specific case of a cascaded hydropower system is presented in Sect. 3.3 with examples how different spatial boundaries will affect the water consumption estimates for the different plants.

\subsubsection{Setting the spatial boundaries}

Based on the review presented in Sect. 2 it appears that the spatial averaged studies (e.g., Gleick, 1993; Gerbens-Leenes et al., 2009) calculate the water consumption by simply dividing evaporation from the surface of the water reservoirs (in the desired region) by the annual hydropower production within the same area. For the single-plant studies, the water consumption is in most cases calculated by dividing the evaporation from the reservoir by the power production from the power plant in the direct vicinity of the reservoir. This defines the reservoir and the power plant directly linked to it as the spatial system boundary. However, we consider that a hydropower scheme can often be much more complex than this. The design of the hydropower system is also very sitespecific as it is very dependent on the opportunities offered by the topography (IPCC, 2012). 


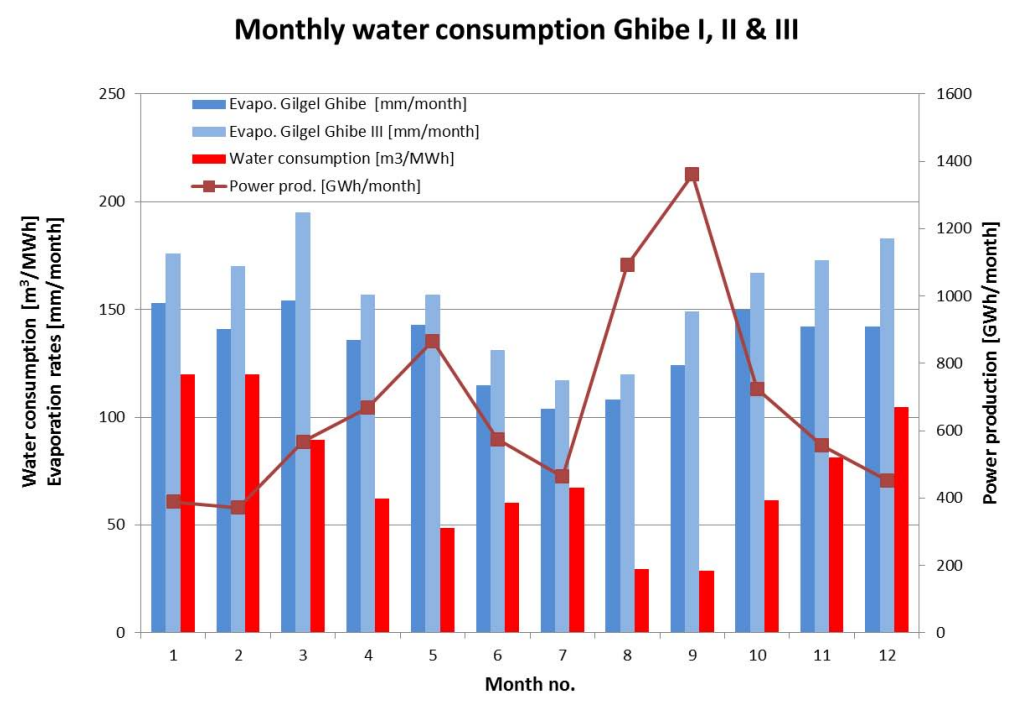

Fig. 3. The graph presents the monthly evaporation rates from the two reservoirs supplying Ghibe I, II and III power plants with water, monthly power production from the year 2005 and correspondingly monthly (gross) water consumption estimates (based on Yesuf, 2012).

A storage-based hydropower system consists of a reservoir in the upper part that aims at collecting water from the upstream catchment and provides regulating services to the downstream production units. It might be several intakes and tunnels from neighboring catchments collecting water into the upstream reservoir, like Statkraft's Ulla-Førre (Statkraft, 2013) with the consequence that rivers and lakes downstream of the intake experience reduced flows. In the case of a high-altitude reservoir, the original free-flowing river is often shortcut by tunnels leading to the hydropower station located at the bottom of the valley, thus creating a bypass section with dramatically reduced flow. Downstream of the outlet, the same volume of water is available again, however, with a changed periodicity caused by the regulation. Further downstream of the outlet from the uppermost hydropower plant, there could be a series of plants benefitting from the regulation provided by the reservoir, or, depending of the topography, a new reservoir/lake could form the basis for the regulation of another series of hydropower plants. One power plant may have tunnels coming from several reservoirs and may also, where opportunities exist, be connected to neighboring watersheds or rivers (IPCC, 2012), but again, determined by the topography. The groundwater levels might also be affected by the river regulation, especially in those areas directly connected to the established reservoir, but also in other areas of water bodies experiencing changes in the hydrological regime. A run-of-the river plant mainly produces electricity from the available river water, and affects the natural hydrology to a less extent than a reservoir-based plant. In addition to the direct hydrological changes, the establishment of a reservoir might also introduce changes in land and water use and management practices. As an example, the improved availability of water can turn the agricultural practice from rain-fed to irrigated crop production.

The concluding message is that a hydropower system can be very complex affecting a large number of water bodies, possibly introducing large changes in flow from the natural hydrological conditions. Based on this, we would argue that the spatial system boundaries are not always the reservoir and the immediately connected hydropower plant as the reservoir can serve several plants with regulated flow and a large number of water bodies might be affected by the regulation, even outside the catchment of the reservoirs and power plants. In the reviewed studies it is also assumed that the evaporated water is "lost" from the system. This water might, however, fall into the upstream part of the catchment and ultimately end up in the same reservoir again.

\subsubsection{Setting the temporal boundaries}

We assume that the estimates presenting water consumption in Sects. 2.2 and 2.3 are all based on annual data (i.e., the evaporation rates and power production are both annual numbers). This is not always explicitly expressed, and there are studies calculating the water footprint on a monthly basis (e.g., Zeng et al., 2012; Hoekstra et al., 2012). As the periodicity is important to consider, an example derived from the work of Yesuf (2012) is presented (Fig. 3).

In Fig. 3 it can be seen that the water consumption rates vary substantially from month to month even though there is a limited change in the evaporation rates (e.g., from month 7 to month 8). The reason for this is the decrease in the power production, and not a reduction in the total water losses (due to reduced surface areas) as the inflow to the reservoirs does not decrease in this period, actually rather the opposite occurs (Yesuf, 2012). If the power production drops further, 
which happened in October in 1984, 1991, 1996 and 2002 (Yesuf, 2012), we will experience that the water consumption values will increase to infinity. Assuming constant evaporation rates, periods with high power production have a lower water footprint than those periods with low production. It should also be mentioned that some hydropower plants are constructed for the purpose of serving peak-load to the electricity system, and will hence have large variations in production over the day, week, season or year.

Similarly, the inter-annual changes in inflow to the reservoir and the corresponding power production might give very different water consumption from year to year. The sitespecific shape of the reservoir (water level-surface areavolume relationship) will determine the variation total evaporation for different inflows (given similar meteorological conditions), but as the relative volume of the reservoir decreases faster than the surface area (and hence evaporation) with a drop in water level, years with low inflow/power production have generally have a higher water footprint than years with high inflow/production. As hydropower might have a lower priority than both drinking water supply and irrigation in multi-purpose reservoirs, the hydropower production might be even more reduced in dry years as other purposes must be fulfilled before water is allocated for electricity production. This might be in line with the idea of the water footprint, but taking into account the possible impact from a high water footprint it is more likely that the impacts from a high water footprint is larger in dry years than in wet years.

We would hence ask for greater attention to selection of the time step of the calculation, as well as the time period (years) the data used in the calculation is taken from. Both the evaporation rates and power production vary on annual timescales, evaporation due to variation and changes in climate and land use whereas power production is also influenced by economical, technological and social factors. A well-know quasi-periodicity of climate is the El Niñosouthern oscillation (ENSO), whereas trends has been observed in past climate and predicted for the future climate. If the aim is to assess the water footprint for the coming years, it is important to consider both periodicities and trends in evaporation and power production and, if necessary, project trends into the future. Both too short and too long averaging periods might introduce biases if periodicities and trends, respectively, are important (Wörman et al., 2010). The given water footprint estimates should be stamped with which time period they are calculated from. In addition, an assessment of estimation uncertainty will be valuable for supporting decisions.

\subsubsection{From selected phases to full life cycle}

A life-cycle assessment (LCA) is a method which calculates the environmental burdens associated with a product system or activity, based on the entire life cycle of the product/activity (from "cradle to grave"). According to the definition of the water footprint (Hoekstra et al., 2011) "the water footprint of a product is the volume of freshwater used to produce the product, measured over the full supply chain". All the three discussed approaches for calculating the water consumption of hydropower plants include only the operational phase of the plan. According to Inhaber (2004) and Fthenakis and Kim (2010) the other lifecycle phases produce a much lower water footprint than the operational phase, but as far as the authors know, no entire life-cycle assessment of the water consumption from hydropower projects has been performed. Such a study should also include the planning and project preparation, construction phase and the decommissioning. Including also other phases than the operational phase will, of course, increase the water consumption of electricity production from hydropower. Incorporating all life-stages is also important in order to enable comparison of water consumption between technologies. This also leads to the question regarding the assignment of life period/span for the plants.

\subsection{The specifics of reservoirs in a cascaded systems}

A common way of developing hydropower resources in a river basin is to construct a series of plants ("cascade") using one or a few reservoirs regulating the whole system. The reservoirs will typically be located in the upstream part of the system, where the topography is usually more favorable for the construction of a reservoir and are often less densely populated areas, thus reducing the potential social conflicts. The upstream reservoir will then provide regulating services for several of the downstream hydropower plants and the operation of these downstream plants will to a large extent be determined by the upstream release of water. There are numerous examples of such regulation schemes worldwide and well-known hydropower systems developed this way are Omo-Ghibe in Ethiopia/Kenya (as presented in Sect. 3.2.2 and later in this section), Akosombo-Kpong in Ghana (as pointed out by Mekonnen and Hoekstra, 2012) and the upper part and side-arms of Mekong River. Lake Selbusjøen and Lake Blåsjø provide similar regulating services for NeaNidelva and Ulla-Førre system (Statkraft, 2013), respectively, as more or less arbitrary examples from Norway.

In order to illustrate how the water consumption will vary depending on the spatial system boundaries we use Mandal River basin in southern Norway (Fig. 4), where the reservoirs (especially Nåvann and Juvann) in the upper parts of the system to a large extent regulate the inflow to all downstream hydropower plants. The degree of regulation will vary from plant to plant as new and unregulated flow from tributaries enters the main river where power plants are located. The polygons drawn on top of the sketch in Fig. 4 represent the different spatial system boundaries, where the water losses from the reservoirs within the same spatial boundary are distributed uniformly between the power plants. 


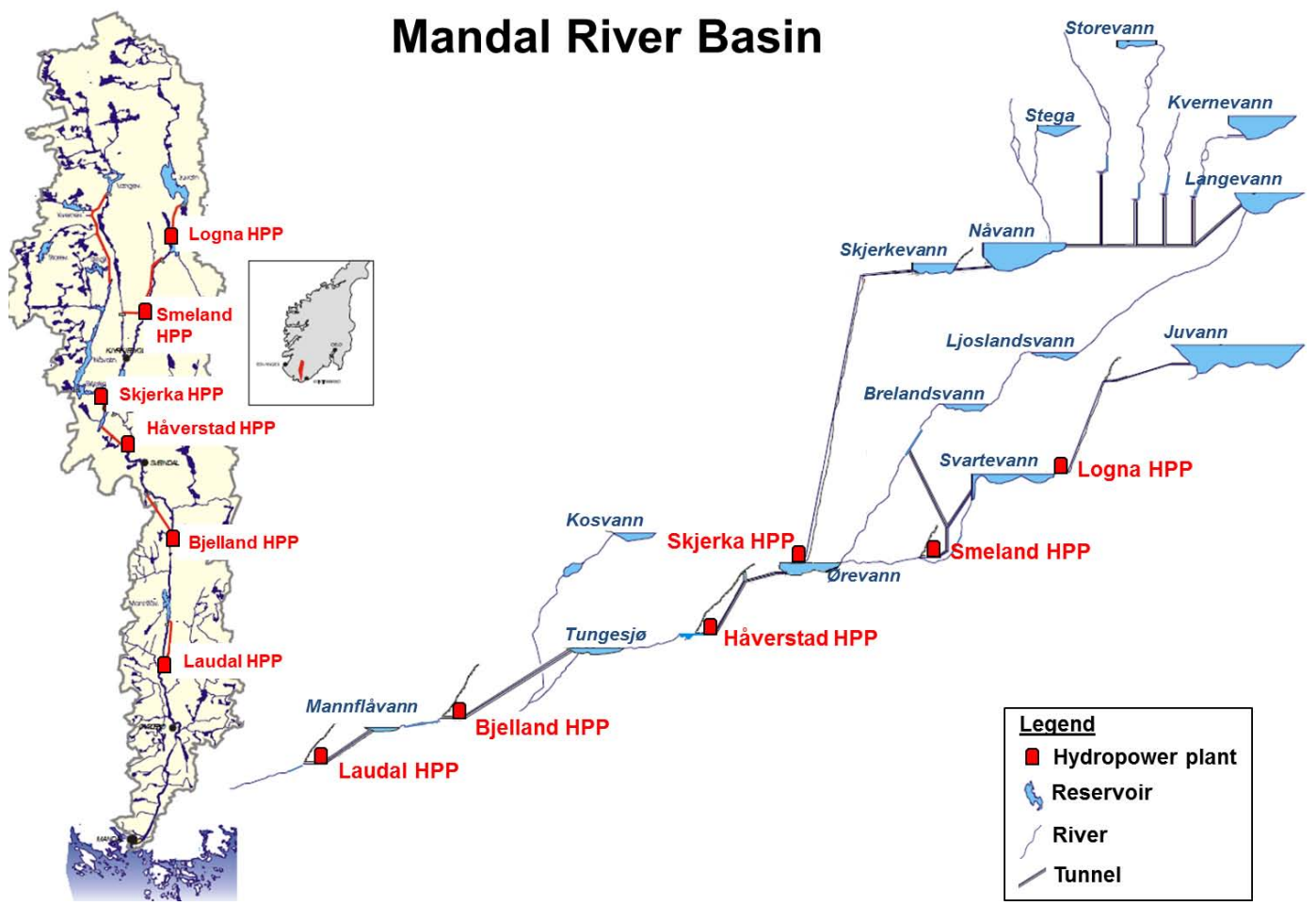

Fig. 4. Schematically view of Mandal River basin, including reservoirs and power plants. Modified from Agder Energi (2013).

In order to illustrate the effect on the water consumption estimates three different spatial system boundaries have been defined (see results in Table 2):

- system boundary 1 (SB 1): the system boundaries are set around the power plant and the immediate upstream reservoir (i.e., all the water consumption is allocated to the closest downstream hydropower plant).

- system boundary 2 (SB 2): the whole river basin is handled as one system, distributing the total evaporation losses between all plants flat or weighted according to energy production.

- system boundary 3 (SB 3): the system boundaries divert the system into two upstream branches and one lower part, that is, Skjerka and the upstream reservoir capacity is handled separately from the Smeland/Logna-branch. The lower part (Håverstad, Bjelland and Laudal) is handled as a third and separate unit.

Another and a much less complex regulated system is the Omo-Ghibe River basin, as also described in Sect. 3.2.2. The Ghigel-Ghibe reservoir in the upstream end serves regulated water to both Ghibe I and Ghibe II. Key information to calculate the water consumption is given in Table 3 . It is assumed that no additional evaporation losses happen on the river stretch between Ghibe I and Ghibe II. System boundary 1 refers to setting the boundary around Ghigel-Ghibe reservoir and Ghibe I only. System boundary 2 includes both Ghibe I and II, and the water consumption numbers are assigned with a flat and weighted (with respect to power production) approach. The results are presented in Table 3 together with characteristics of the plants and reservoir.

Based on the results from Mandal River basin and OmoGhibe River basin (Tables 2 and 3, respectively), we can see that the definition of the spatial system boundaries considerably affects the water consumption estimates, and we call for clarification about how this should be done in a way that captures the complexity of a large number of hydropower projects. The water consumption of Bjelland power plant (Mandal River basin) will vary from 0.75 to $21.7 \mathrm{~m}^{3} \mathrm{MWh}^{-1}$, depending on the system boundaries. From the case in Omo-Ghibe River basin we can read that if Ghibe II is treated as a run-of-the-river (R-O-R) plant with no reservoir, the water consumption is $0 \mathrm{~m}^{3} \mathrm{MWh}^{-1}$, while if it is acknowledged that this plant also benefits from the upstream reservoir the water consumption vary from 30.5$42.4 \mathrm{~m}^{3} \mathrm{MWh}^{-1}$, depending on how the reservoir losses are distributed between Ghibe I and II. It is worthwhile noting that Demeke et al. (2013) has estimated the water consumption for Gilgel Ghibe I to $142.4 \mathrm{~m}^{3} \mathrm{MWh}^{-1}$ (using the average evaporation rates), which fits well with the calculated water consumption rates in our paper, using system boundary $1\left(138.3 \mathrm{~m}^{3} \mathrm{MWh}^{-1}\right)$.

Water consumption estimates have been prepared for Akosombo by both Mekonnen and Hoekstra (2012) and Demeke 
Table 2. Power plants, annual production and corresponding water consumption estimates for three different approaches for setting the spatial system boundaries for the cascaded regulation in Mandal River basin. The estimates given in the three columns to the right refer to flat and weighted (with respect to power production) water consumption numbers, respectively. Data sources: Agder Energi (2013), NVE Atlas (2013) and Beldring et al. (2002).

\begin{tabular}{|c|c|c|c|c|c|c|c|}
\hline \multirow{2}{*}{$\begin{array}{l}\text { Power } \\
\text { plant }\end{array}$} & \multirow{2}{*}{$\begin{array}{c}\text { Annual } \\
\text { production } \\
{\left[\mathrm{GWh} \mathrm{yr}^{-1}\right]}\end{array}$} & \multirow{2}{*}{$\begin{array}{l}\text { Surface at } \\
\text { reservoir } \\
\text { directly } \\
\text { connected } \\
{\left[\mathrm{km}^{2}\right]^{\mathrm{a}}}\end{array}$} & \multirow{2}{*}{$\begin{array}{r}\text { Acc. } \\
\text { reservoir } \\
\text { surface } \\
\text { area }\left[\mathrm{km}^{2}\right]\end{array}$} & \multirow{2}{*}{$\begin{array}{l}\text { Evaporation } \\
\qquad[\mathrm{mm}]^{\mathrm{b}}\end{array}$} & \multicolumn{3}{|c|}{ Water consumption estimate $\left[\mathrm{m}^{3} \mathrm{MWh}^{-1}\right]$} \\
\hline & & & & & SB 1 & $\begin{array}{l}\text { SB } 2 \\
\text { Flat/weighted }^{\mathrm{c}}\end{array}$ & $\begin{array}{r}\text { SB 3 } \\
\text { Flat/weighted }\end{array}$ \\
\hline Logna & 105 & 8.1 & 8.1 & 450 & 34.8 & $9.9 / 24.7$ & $53.5 / 57.1$ \\
\hline Smeland & 119 & 1.6 & 12.0 & 450 & 6.1 & $9.9 / 21.8$ & $53.5 / 50.4$ \\
\hline Skjerka & 612 & 1.7 & 28.3 & 450 & 1.3 & $9.9 / 4.2$ & $26.6 / 26.6$ \\
\hline Håverstad & 282 & 3.8 & 32.1 & 450 & 6.1 & $9.9 / 9.2$ & $8.6 / 7.5$ \\
\hline Bjelland & 312 & 0.5 & 32.6 & 450 & 0.8 & $9.9 / 8.3$ & $8.6 / 6.8$ \\
\hline Laudal & 146 & 2.0 & 34.6 & 450 & 6.2 & $9.9 / 17.8$ & $8.6 / 14.5$ \\
\hline
\end{tabular}

${ }^{a}$ The number given for Skjerka includes only Skjerkevann, not Nåvann and Langevann. ${ }^{b}$ The evaporation rates should be given for each reservoir, but will for each power plant vary according to which reservoirs that are assigned to each power plant, i.e., the spatial system boundaries. ${ }^{\mathrm{c}}$ The evaporation losses are distributed with an even share on all plants, and these numbers are divided on the actual production for each plant.

Table 3. Characteristics and water consumption estimates for Ghibe I and II. The power production data are average production values for a non-specified period. Primary source: Yesuf (2012).

\begin{tabular}{|c|c|c|c|c|c|}
\hline \multirow{2}{*}{$\begin{array}{l}\text { Power } \\
\text { plant }\end{array}$} & \multirow{2}{*}{$\begin{array}{r}\text { Annual } \\
\text { production } \\
{\left[\mathrm{GWh} \mathrm{yr}^{-1}\right]}\end{array}$} & \multirow{2}{*}{$\begin{array}{l}\text { Accumulated } \\
\text { reservoir } \\
\text { surface area } \\
{\left[\mathrm{km}^{2}\right]^{\mathrm{a}}}\end{array}$} & \multirow{2}{*}{$\begin{array}{c}\text { Evaporation } \\
{[\mathrm{mm}]}\end{array}$} & \multicolumn{2}{|c|}{ Water consumption estimate $\left[\mathrm{m}^{3} \mathrm{MWh}^{-1}\right]^{\mathrm{b}}$} \\
\hline & & & & System boundary 1 & $\begin{array}{l}\text { System boundary } 2 \\
\text { Flat/weighted }\end{array}$ \\
\hline Ghibe I & 722 & 62 & 1611 & 138.3 & $42.4 / 69.2$ \\
\hline Ghibe II & 1635 & 62 & 1611 & 0 & $42.4 / 30.5$ \\
\hline
\end{tabular}

a The reservoir area is taken from Yewhalaw et al. (2009) as this is not given in Yesuf (2012). ${ }^{\mathrm{b}}$ The reader should note that these numbers differ from those given in Table 1 from the same publication, w hich is first of all due to the fact that data from the planned Ghibe III (with a new, large reservoir) are used in the calculations presented in Table 1, hence affecting the results. Furthermore, the data on power production and evaporation originate from different periods and that there might also be differences in the reservoir area used in the calculation.

et al. (2013), giving estimates on 3046 and $2656 \mathrm{~m}^{3} \mathrm{MWh}^{-1}$, respectively. Mekonnen and Hoekstra (2012) states that they calculate the water footprint for the combined Akosombo-Kpong system, while this information is not provided by Demeke et al. (2013). The evaporation rates used in the calculations explain some of the differences in the water consumption estimates, where Demeke et al. (2013) use the mean value from several years of measurements $\left(1500 \mathrm{~mm} \mathrm{yr}^{-1}\right)$, while the evaporation values (2185 $\mathrm{mm} \mathrm{yr}^{-1}$ ) used by Mekonnen and Hoekstra (2012) are calculated based on the Penman-Monteith equation.

From these cases we can conclude that a simplistic approach of calculating the water consumption/footprint would possibly give a very biased picture on how water losses should be assigned in a fair way. Defining the system boundaries to the reservoir and the immediate hydropower plant would typically overestimate the water consumption for this individual plant. A fairer approach would be to distribute these losses also to the downstream plants benefitting from the reservoir.

We would also underline that the methodological approach applied in our cases also make several rough simplifications, e.g., with respect to changes in surface area of the other water bodies and rivers affected by the regulation, ignoring the transfer of water between catchments and the variation in flow, evaporation rates and power production throughout the year. There are also hydropower plants that periodically are operated with water originating from different reservoirs.

Furthermore, we would like to draw the attention to the fact that hydropower systems might also include pumpstorage plants (PSPs) which will add further complexity to the analysis. Development of PSPs is expected to increase the coming years due to extensive development of non-regulated renewable energy sources (Gabrielsen and Grue, 2012) that needs regulating services, where hydropower is expected to play an important role. Existing reservoirs might have their typical regulations regimes changed (Solvang et al., 2012) 

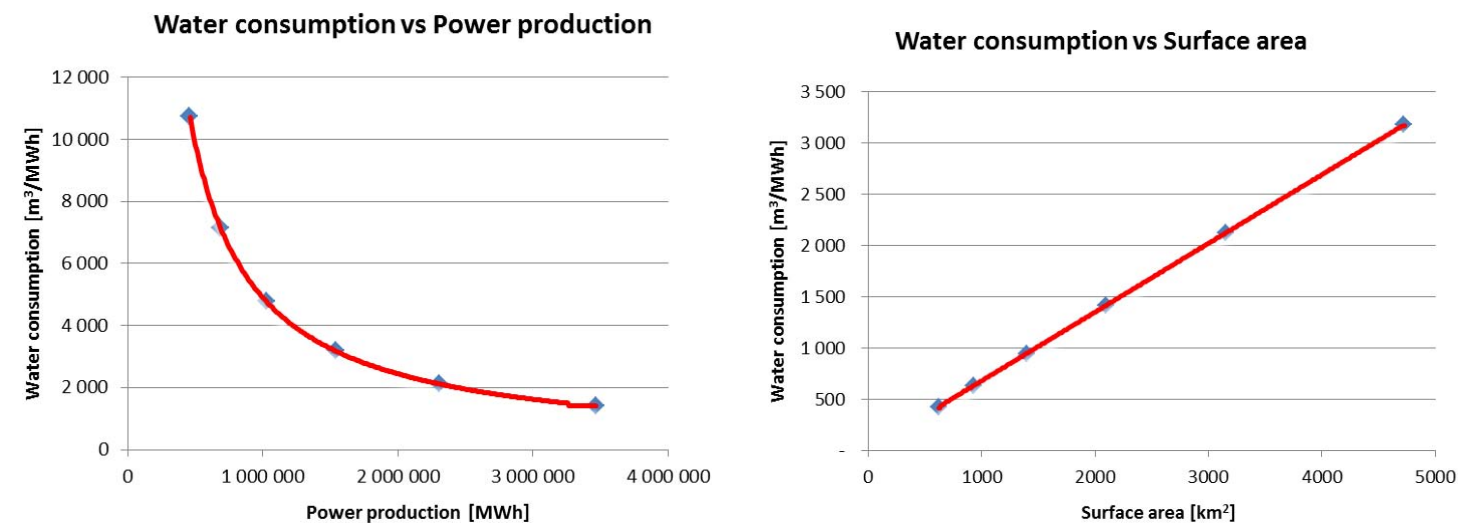

Fig. 5. The graphs present estimated water consumption from the planned Beles Hydroelectric Power Plant in Ethiopia (black rings on the graph) with use of Lake Tana as the reservoir (Tefferi, 2012), and illustrates also how the water consumption will vary with power production (left panel) and surface area (right panel).

and new reservoirs possibly constructed. Calculation of the water losses and the net energy production within the total system and for the individual plants will be challenging.

\subsection{Use of existing lakes as reservoirs}

Norway is naturally blessed with numerous natural lakes and a large number of them are located up in the mountains, close to edges diving steeply to lower altitudes and in areas with high precipitation rates. Use of these upstream lakes appeared ideal as reservoirs and has been a very common and economical way of developing hydropower systems in Norway (Hveding, 1992) with limited changes to the landscape. Outside Norway there are also a large number of lakes utilized as reservoirs for hydropower production and other purposes, where Lake Victoria, Lake Malawi and Lake Tana are well-known cases. Tapping water for hydropower production to a downstream power plant would make literally no changes in the evaporation from the surface, given that the regulation of the lake is within the same range of the water level fluctuations as prior to the hydropower development. It appears surprising that adding a hydropower plant to the system without changing the nature of the lake significantly should justify that a large water loss is assigned to the plant. It also appears strange that the larger the lake becomes the larger the water consumption estimates are (Fig. 5, right panel). Similarly, the water consumption rates will increase with a decrease in the energy production, given the same evaporation rates and constant surface area (Fig. 5, left panel). The water consumption will increase into infinity as the production decreases to zero, which makes little sense. In the case of using the net evaporation rates instead of the gross evaporation rates, the water consumption rates using a natural lake as a reservoir will be close to zero.

On the other extreme, do hydropower plants without reservoirs (i.e., run-of-the-river plants (R-O-R) with only a small intake pond to stabilize the inflow) have a zero water footprint? Assuming that all the water consumption originates from the reservoir the current dominating methodology would free R-O-R hydropower from the burden of a water footprint.

\subsection{Assignment of losses in multi-purpose reservoirs}

Approximately $25 \%$ of the world's reservoirs with a dam higher than 15 meters are multi-purpose reservoirs (ICOLD's World Register of dams, 2013). Out of 8689 reservoirs serving hydropower production, 3775 are also used for other purposes. Many of these purposes have defined water requirements as withdrawal of a certain volume of water during a defined time period (e.g., $\mathrm{m}^{3} \mathrm{~s}^{-1}$ or mil. $\mathrm{m}^{3} \mathrm{month}^{-1}$ ). Many reservoirs serve as a means of flood protection, and the capacity of this service is defined as a certain reservoir volume available to buffer large inflows (flood events) in order to reduce the downstream risks of a devastating flood (e.g., Liu et al., 2013). This purpose thus cannot be handled by the same analytical approach as the other types of uses typically requiring withdrawal of water.

An example of a multi-purpose reservoir is the Sri Ram Sagar Project (SRSP) on the Godavari River basin in the State of Andrah Pradesh in India. This reservoir serves water for the following purposes, given in the priorities order according to the State Water Policies and the National Water Policy for water management practices (Andrah Pradesh, 2013): 1. Drinking water; 2. Irrigation; 3. Hydropower generation; 4. Industry; 5. Fisheries; and 6. Environmental flows.

In the case of SRPS, only the three first purposes are relevant in the context of water allocation (Sauterleute et al., 2012). It should also be mentioned that the hydropower production is directly determined by the release of water for irrigation via one of the irrigation canals. Further characteristics of SRPS are given in Tables 4 and 5.

In Table 6 and Fig. 6 the calculated water consumption values for the hydropower plant in the multi-purpose SRPS 
Table 4. Key characteristics of the reservoir and the hydropower production of SRPS. Source: Sauterleute et al. (2012).

\begin{tabular}{lll}
\hline Characteristics & Value & Unit \\
\hline Surface area of reservoir $_{\text {Installed capacity }}$ & 453 & $\mathrm{~km}^{2}$ \\
Estimated annual energy production $^{\mathrm{a}}$ & 36 & $\mathrm{MW}$ \\
Estimated annual evaporation losses $^{\mathrm{b}}$ & 236.5 & $\mathrm{GWh}$ \\
Estimated total annual evaporation losses $^{2}$ & 7696 & $\mathrm{~mm}$ \\
\hline
\end{tabular}

a Assumed $75 \%$ period of use $(6570 \mathrm{~h})$ of full capacity, which is probably an optimistic estimate. ${ }^{b}$ Based on evaporation data from the gauging station Hydro-Meteorological station Ramagundam of the SRPS (documented in internal note).

is made with various models for attributing water losses to the hydropower production.

We emphasize that the water values and allocation ratios are very site-specific and transfer of these data should be avoided in a real case. The reason we include the water values from Kadigi et al. (2008) and M. J. Pasqualetti and S. Kelly (personal communication, 2008) are for the purpose of illustrating the effect the use of water values might have on the attribution of water consumption might have on hydropower. Given the complexity of this example of SRSP, which is not unique, it appears very difficult to assign the burden of the water losses between the different purposes, and not fairly assign all the losses to the hydropower production. It should also be noted that the given calculations take only irrigation, hydropower and drinking water into consideration, and no other social or environmental benefits such as flood control.

The publication by M. J. Pasqualetti and S. Kelly (personal communication, 2008) should be mentioned specifically as this is one of the few publications that have made an attempt to assign the water losses to the different water uses. In this publication the approach was to assign a financial value to all of the uses of the water, namely electricity production, recreation, agriculture and domestic water supply, using the wholesale price sale of water. This was demonstrated for the case of Glen Canyon Dam storing the water of Lake Powell, giving $55 \%$ of the burden to hydropower. We would, however, underline that the financial value does not tell the whole story, as "social value" of water, for example irrigation might be very high (Kadigi et al., 2008).

The order of the development should maybe also be considered when assigning the water losses to the various uses. It could be argued that water uses that arise after the construction of the reservoir should only be assigned those extra water losses caused by the new activity. As in SRPS there is potential to generate electricity in many irrigation systems, both by using the head directly at the dam site and from low head generation systems within the canals (e.g., US National Hydropower Association, 2013). This would generate benefits to areas with limited and unreliable electricity supply

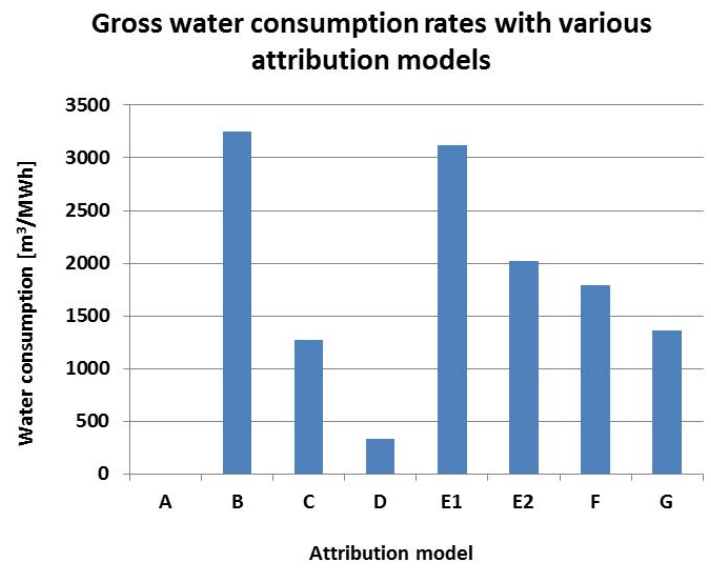

Fig. 6. The water consumption for hydropower in a multi-purpose reservoir, given different models to attribute losses. The figure is based on the numbers given in Table 6 , where also the description of the models can be found.

with basically no negative impacts to other water user (nor changes in evaporation). If the hydropower generation from these systems is attributed a large water footprint, possibly with a high reputational risk for an energy developer, this might stop sound projects, which is an undesired outcome seen from all perspectives.

How much of the water consumption should be attributed to hydropower generation is controversial. Different approaches for distributing the losses will lead to a wide range of estimates in multi-purpose reservoirs. As multi-purpose reservoirs are very common and rather the rule than the exception, we would argue that a methodology for estimating water consumption from such reservoirs must be developed in order to calculate credible estimates. This is also supported by Mekonnen and Hoekstra (2012) and Demeke et al. (2013) that both urge the need for a methodology to distribute the water losses in the case of multi-purpose reservoirs.

\subsection{The water footprint concept and its lack of connection to impact}

Calculation of the $\mathrm{CO}_{2}$ footprint could be seen as a parallel to the calculation of a water footprint. In contrast to $\mathrm{CO}_{2}$, water is a local resource with local impacts if it is not managed properly. While emissions of $\mathrm{CO}_{2}$ add to the global pool (atmosphere) of $\mathrm{CO}_{2}$, the water losses are not a global loss of a resource, but have only local or regional impacts (basically within the river basin). The impact of emitting $1 \mathrm{t}$ of $\mathrm{CO}_{2}$ is independent of place while the impact of consuming $1 \mathrm{~m}^{3}$ can only be determined by the local situation. Considering water on a global scale, it is not lost or used up due to evaporation. Increased losses or water footprints of electricity production will not cause any imbalance to the global hydrological cycle. We would hence argue that the water consumption must be accompanied by a local or 
Table 5. Assumed average demand fulfillment for the various sectors in the SRPS. Optimal and minimum refer to level of demand fulfillment. Source: Sauterleute et al. (2012).

\begin{tabular}{lrrrrr}
\hline Water use & \multicolumn{2}{c}{$\begin{array}{c}\text { Demand fulfillment } \\
{\left[\text { Mill. }^{3} \text { month }^{-1} \text { ] }\right.}\end{array}$} & & \multicolumn{2}{c}{$\begin{array}{c}\text { Demand fulfillment, ratio of } \\
\text { flow [\%] }\end{array}$} \\
\cline { 2 - 3 } \cline { 5 - 6 } & Optimal & Minimum & & Optimal & Minimum \\
Drinking water supply & 20.1 & 11.3 & & 2.8 & 2.9 \\
Irrigation & 419.1 & 334.1 & & 58.0 & 86.8 \\
Hydropower production* & 283.2 & 39.6 & & 39.2 & 10.3 \\
\hline
\end{tabular}

* Hydropower production and supply of irrigation water via Kakatiya canal (the canal linked with the

hydropower plant) is here assumed as independent of each other.

Table 6. Calculated water consumption values for the hydropower plant in the multi-purpose SRPS with various models for attributing water losses to the hydropower production.

\begin{tabular}{|c|c|c|}
\hline \multicolumn{2}{|r|}{ Approach for assigning the water consumption } & \multirow{2}{*}{$\begin{array}{l}\text { Gross WC assigned to } \\
\text { HP plant }\left[\mathrm{m}^{3} \mathrm{MWh}^{-1}\right] \\
0\end{array}$} \\
\hline A & All losses assigned to the top priority uses (drinking water) & \\
\hline $\mathrm{B}$ & All losses assigned the hydropower plant & 3248 \\
\hline $\mathrm{C}$ & Losses attributed according to water use (Table 5, optimum) & 1273 \\
\hline $\mathrm{D}$ & Losses attributed according to water use (Table 5 , minimum) & 334 \\
\hline E1 & $\begin{array}{l}\text { Attribution according to economic return, using "low" } \\
\text { agricultural values from Kadigi et al. }(2008)^{\mathrm{a}}\end{array}$ & 3121 \\
\hline E2 & $\begin{array}{l}\text { Attribution according to economic return, using "default" } \\
\text { agricultural values from Kadigi et al. }(2008)^{\mathrm{b}}\end{array}$ & 2016 \\
\hline $\mathrm{F}$ & $\begin{array}{l}\text { Attribution according to water value principle, using water } \\
\text { values from M. J. Pasqualetti and S. Kelly (personal communication, 2008) }\end{array}$ & 1787 \\
\hline G & $\begin{array}{l}\text { Attribution according to allocation ratios given by Jain } \\
(2007)^{c} \text { - giving a } 42 \% \text { share to hydropower }\end{array}$ & 1364 \\
\hline
\end{tabular}

regional study on the impacts of the water resources. This is also supported by the IPCC (2012) that underlines that the impacts "are site specific and need to be considered with respect to local resources and needs. RE technologies like hydropower and some bioenergy systems, for example, are dependent on water availability and can either increase competition or mitigate water scarcity". This topic is, however, controversial and our views are supported by for instance Pfister and Hellweg (2009), Berger and Finkbeiner (2010) and Chenoweth et al. (2013), but not by Mekonnen and Hoekstra (2012).

A mature and well-tested methodology of assessing the impacts on the water resources is not available, but a number of attempts can be found. Zeng et al. (2012) demonstrates the water footprint sustainability assessment, defined by Hoekstra et al. (2011) on a river basin level, where a "sustainability concern" should be raised when the water footprint exceeds the available blue water component (Hoekstra et al., 2011). The blue water is defined as the blue water resources under natural conditions and without human intervention, subtracted the environmental flow requirements.

Ridoutt and Pfister (2010) propose that a water impact index should be linked to how certain types of human activity might contribute to water scarcity and hence reduce the availability of freshwater resources for both human use and the environment. This approach is developed with agricultural production in mind. Pfister et al. (2011) propose an approach for assessing water consumption and impact from power production by introducing climatic data, where potential evaporation affects the water consumption according to the traditional approach, and aridity relates to the water availability.

Finally, we believe that a methodology for assessing the impact should also take on board the fact that a reservoir improves the availability of water for many water users. This is further explored in the following section. 


\subsection{The paradox of the water footprint of the reservoir}

Storage of water from the wet season to the dry season in reservoirs is acknowledged as the most common, efficient and maybe the only possible way of storing large volumes of water for longer periods (van Steenbergen et al., 2011). By use of reservoirs civilizations have to large extent overcome the risk of famine and reservoirs linked with irrigation canals have supported the development of a farming system with much higher and more reliable yields (e.g., Liu et al., 2013). Reservoirs have enabled societies to have access to a secure supply of water in periods with literally no natural runoff. A recent publication (UNICEF and World Health Organization, 2012) states that as many as 780 million people still lack access to adequate drinking water services. On top of this, predictions for climate change indicate that changes in rainfall patterns and temperatures, combined with population growth, may add even more pressure on scarce water resources (Bates et al., 2008). Given this situation, a water manager will strive to make the management of these resources even more efficient in order to save and protect this precious resource.

There is "no way" around the fact that the evaporation losses from reservoirs are very large in many regions, but there is a pertinent question to ask then; would a water manager start removing dams and reservoirs in order to reduce the water footprint of human activities within his or her jurisdiction in order to increase the water that is available for other purposes? The answer to this is most likely no, as we would guess the strategy of the water manager would be the opposite (i.e., build more reservoirs in order to catch the runoff from disappearing into the ocean). Reservoirs are acknowledged as an important part of the infrastructure in order to cope with climate change to secure water supply in the future (Bates et al., 2008). In many regions climate changes will reduce precipitation further and additional reservoirs are necessary (Harman et al., 2005).

The development of the building block method (BBM) (Tharme and King, 1998) was originally developed to assess environmental and downstream flows. This approach has been used in a number of cases for this purpose (Bakken et al., 2012) and has also been tested as an approach to set water level regulation (Skarbøvik et al., 2011) and for water allocation between competing water uses (Bakken et al., 2013b). The idea of the BBM is that improved water management should be reached by the involvement of experts and stakeholders in workshops where different water allocation regimes are discussed and optimum flow conditions are set in a process that is supposed to end in consensus. This methodology would be a way to measure to which extent the needs of the various water uses is fulfilled and hence be a proxy for change in water availability.

We argue that the methodology for the assessment of the water footprint of hydropower plants with reservoirs, as defined "to analyze how human activities or specific products relate to issues of water scarcity and pollution, and to see how activities and products can become more sustainable from a water perspective" (Hoekstra et al., 2011) fails in this purpose, since defining a management strategy based on the water footprint of reservoirs would lead to a wrong management action.

\section{Conclusions}

More studies on water consumption from hydropower are now available since the report from IPCC on renewable energy (IPCC, 2012) was published. The IPCC report was based on very few sources providing a wide range in their estimates compared to the other technologies. The newly published studies, however, do not provide a more consistent picture about what the "true" water consumption from hydropower plants is, as some of the new studies are far beyond earlier published values on hydropower (Mekonnen and Hoekstra, 2012; Tefferi, 2012).

This review reveals that three different methodological approaches have been used, namely the gross and net evaporation (Eqs. 1 and 2, respectively) and the water balance method published by Herath et al. (2011), where the first approach (gross evaporation divided by annual power production) is the dominating method. The water footprint of hydropower is calculated using the same simplistic approach based on gross evaporation rates (Mekonnen and Hoekstra, 2012). In the cases where both the gross and the net water consumption estimates are calculated, the net values are in the range of approx. $12-60 \%$ of the gross water consumption.

The analysis of the compiled data set of single-plant estimates was diversified with respect to climatic zone (Köppen, 1936) and shows that the water consumption estimates from climatic zones A and B appear to be higher than especially those from zones D and $\mathrm{E}$. These conclusions are based on limited data. The difference in water consumption values between the climatic zones (A and C) decreases considerably when calculating the average net water consumption estimates compared to the gross values. We believe that an oversimplistic calculation method combined with a lack of refinement of the data set makes it difficult to identify further trends in the material.

This study documents and discusses several methodological problems when applying this simplified approach (gross evaporation divided by annual power production) for the estimation of water consumption from hydropower projects. As hydropower projects are very site specific, the methodological approach is to a little extent suitable for this technology. A number of short-comings are identified, including the lack of clarity regarding the setting of proper system boundaries in space and time. This affects the results from cascaded systems considerably, as well as possibly giving a biased picture of the temporal distribution of the water consumption. 
The methodology of attributing the water losses to the various uses in multi-purpose reservoirs is not developed. Furthermore, a proper and fair methodology for handling water consumption in reservoirs based on natural lakes is needed, as it appears meaningless that all the evaporation losses from a close to natural lake should be attributed to the hydropower production. It also appears problematic that the concept is not related to the impact the water consumption will have on the local water resources, as high water consumption values might not be problematic per se. Finally, it appears as a paradox that a reservoir might end up with very high water consumption/footprint and still be the most feasible measure to improve the availability of water in a region. We argue that reservoirs are not always the problem, but might rather be the solution to problems of water scarcity. The authors urge for an improved conceptual framework in order calculate the water footprint from hydropower projects.

Acknowledgements. The study has received financial support via EcoManage, funded by the Research Council of Norway (contract no. 215934/E20). EcoManage is organized under the research centre CEDREN (Centre for Environmental Design of Renewable Energy - www.cedren.no).

Edited by: J. Liu

\section{References}

Agder Energi: www.ae.no/ae/english/, last access: 21 August 2013. Andrah Pradesh (India): State Water Policies and the National Water Policy for water management practices, http://wrmin.nic.in/ writereaddata/linkimages/anu29668628373.pdf, last access: August 2013 .

Arnøy, S.: Water Footprint Approaches in Life Cycle Assessment: State-of-the-Art and a Case Study of Hydroelectric Generation in the Høyanger Area, Master's thesis at Norwegian University of Life Sciences (UMB), Ås, Norway, 2012.

Bakken, T. H., Zinke, P., Melcher, A., Sundt, H., Vehanen, T., Jorde, K., and Acreman, M.: Setting environmental flows in regulated rivers, SINTEF report Serial No. TR A7246, SINTEF Energy Research, Trondheim, Norway, 2012.

Bakken, T. H., Killingtveit, Å., Engeland, K., Alfredsen, K., and Harby, A.: Water consumption from hydropower production: review of published estimates, in: Considering Hydrological Change in Reservoir Planning and Management, edited by: Schumann, A., IAHS Press, 2013a.

Bakken, T. H., Skarbøvik, E., Gosain, A. K., Palanisami, K., Sauterleute, J., Egeland, H., Kakumanu, K. R., Nagothu, U. S., Harby, A., Tirupataiah, K., and Stålnacke, P.: Water Allocation With Use of the Building Block Methodology (BBM) in the Godavari Basin, India, J. Sustain. Develop., 6, doi:10.5539/jsd.v6n8p93, 2013b.

Bates, B. C., Kundzewicz, Z. W., Wu, S., and Palutikof, J. P. (Eds.): Climate Change and Water, Technical Paper of the Intergovernmental Panel on Climate Change, IPCC Secretariat, Geneva, 210],pp., 2008.
Beldring, S., Roald, L. A., and Voks $\varnothing$, A.: Avrenningskart for Norge, Årsmiddelverdier for avrenning 1961-1990, Norges vassdrags-og energidirektorat, Norges vassdrags- og energidirektorat, Oslo, Norway, 2002.

Berger, M. and Finkbeiner, M.: Water Footprinting: How to Address Water Use in Life Cycle Assessment?, Sustainability, 2, 919-944, 2010.

Chenoweth, J., Hadjikakou, M., and Zoumides, C.: Review article: Quantifying the human impact on water resources: a critical review of the water footprint concept, Hydrol. Earth Syst. Sci. Discuss., 10, 9389-9433, doi:10.5194/hessd-10-9389-2013, 2013.

Demeke, T. A., Marence, M., and Mynett, A. E.: Evaporation from reservoirs and the hydropower water footprint, in: Proceedings from Africa 2013, 16-18 April 2013, Addis Ababa, Ethiopia, 2013.

Fthenakis, V. and Kim, H. C.: Life-cycle uses of water in U.S. electricity generation, Renew. Sustain. Energy Rev., 14, 2039-2048, 2010.

Gabrielsen, R. H. and Grue, J. (Eds.): Norwegian Energy Policy in Context of the Global Energy Situation, The Norwegian Academy of Science and Letters, Oslo, Norway, 2012.

Gerbens-Leenes, P. W., Hoekstra, A. Y., and van der Meer, Th.: The water footprint of energy from biomass: A quantitative assessment and consequences of an increasing share of bio-energy in energy supply, Ecol. Econom., 68, 1052-1060, 2009.

Gleick, P. H.: Environmental consequences of hydroelectric development: The role of facility size and type, Energy, 17, 735-747, 1992.

Gleick, P. H.: Water in Crisis: A Guide to the World's Fresh Water Resources, Oxford University Press, New York, NY, USA, 1993.

Gleick, P. H.: Water and energy, Annu. Rev. Energy Environ., 19, 267-299, 1994.

Harman, J., Gawith, M., and Calley, M.: Progress on assessing climate impacts through the UK Climate Impacts Programme, Weather, 60, 258-262, 2005.

Herath, I., Deurer, M., Horne, D., Singh, R., and Clothier, B.: The water footprint of hydroelectricity: a methodological comparison from a case study in New Zealand, J. Clean. Prod., 19, 15821589, 2011.

Hoekstra, A. Y., Chapagain, A. K., Aldaya, M. M., and Mekonnen, M. M.: The water footprint assessment manual: Setting the global standard, Earthscan, London, UK, 2011.

Hoekstra, A. Y., Mekonnen, M. M., Chapagain, A. K., Mathews, R. E., and Richter, B. D.: Global Monthly Water Scarcity: Blue Water Footprints versus Blue Water Availability, PLoS ONE, 7, e32688, doi:10.1371/journal.pone.0032688, 2012.

Hutson, S. S., Barber, N. L., Kenny, J. F., Linsey, K. S., Lumia, D. S., and Maupin, M. A.: Estimated use of water in the United States in 2000, US Geological Survey, Virginia, USA, 2004.

Hveding, Q.: Hydropower development in Norway, Vol. 1, Norwegian Institute of Technology, Division of Hydraulic Engineering, Trondheim, Norway, 1992.

ICOLD's World Register of dams: http://www.icold-cigb.net/GB/ World_register/generalsynthesis.asp, last acess: 21 August 2013.

IHA: World Congress Bulletin: Summary of the International Hydropower Association Paper presented at the World Congress on advancing sustainable hydropower, New York, http://www.iisd. ca/ymb/hydro/iha2011/html/ymbvol139num7e.html (last access: 21 August 2013), 2011. 
Inhaber, H.: Water Use in Renewable and Conventional Electricity Production, Energy Sourc., 26, 309-322, 2004.

IPCC: Edenhofer, O., Pichs-Madruga, R., Sokona, Y., Seyboth, K., Matschoss, P., Kadner, S., Zwickel, T., Eickemeier, P., Hansen, G., Schlömer, S., and von Stechow, C. E.: IPCC Special Report on Renewable Energy Sources and Climate Change Mitigation. Cambridge University Press, Cambridge, UK and New York, NY, USA, 2012.

Jain, S. K.: Hydrology and water resources of India, Water Sci. Technol., 57, 388-389, 2007.

Kadigi, R. M. J., Mdoe, N. S. Y., Ashimogo, G. C., and Morardet, S.: Water for irrigation or hydropower generation? Complex questions regarding water allocation in Tanzania, Agr. Water Manage., 95, 984-992, 2008.

Kenny, J. F., Barber, N. L., Hutson, S. S., Linsey, K. S., Lovelace, J. K., and Maupin, M. A.: Estimated Use of Water in the United States in 2005, US Geological Survey Circular vol. 1344, US Geological Survey, Reston, VA, 2009.

Köppen, W.: Das geographisca System der Klimate, in: Handbuch der Klimatologie, edited by: Köppen, W. and Geiger, G. C., Gebr. Borntraeger, 1-44, 1936.

LeCornu, J.: Dams and water management, Report of the Secretary General, International Commission on Large Dams to the Conférence Internationale Eau et Développement Durable, 1921 March 1998, Paris, France, 1998.

Leigh Jr., E. G.: Tropical Forest Ecology, A view from Barro Colorado Island, Oxford University Press, 2009.

Liu, J., Zang, C., Tian, S., Liu, J., Yang, H., Jia, S., You, L., Liu, B., and Zhang, M.: Water conservancy projects in China: achievements, challenges and way forward, Global Environ. Change, 23, 633-643, 2013.

Macknick, J., Newmark, R., Heath, G., and Hallett, K. C.: A Review of Operational Water Consumption and Withdrawal Factors for Electricity Generating Technologies, Technical Report NREL/TP-6A20-50900, National Renewable Energy Laboratories, Colorado, USA, 2011.

Macknick, J., Newmark, R., Heath, G., and Hallett, K. C.: Operational water consumption and withdrawal factors for electricity generating technologies: a review of existing literature. Environ. Res. Lett., 7, 045802, doi:10.1088/1748-9326/7/4/045802, 2012a.

Macknick, J., Sattler, S., Averyt, K., Clemmer, S., and Rogers, J.: The water implications of generating electricity: water use across the United States based on different electricity pathways through 2050, Environ. Res. Lett., 7, 045803, doi:10.1088/17489326/7/4/045803, 2012b.

Mekonnen, M. M. and Hoekstra, A. Y.: The blue water footprint of electricity from hydropower, Hydrol. Earth Syst. Sci., 16, 179187, doi:10.5194/hess-16-179-2012, 2012.

Mielke, E., Anadon, L. D., and Narayanamurti, V.: Water Consumption of Energy Resource Extraction, Processing and Conversion, Discussion Paper No. 2010-15, Harvard Kennedy School, Cambridge, MA, USA, 2010.

Modahl, I. S., Raadal, H. L., Gagnon, L., and Bakken, T. H.: How system boundaries affect the energy indicator results for different electricity generation technologies, Energy Policy, in press, 2013.

NVE Atlas: http://atlas.nve.no/ge/Viewer.aspx?Site=NVEAtlas, last access: 21 August 2013.
Pasqualetti, M. J. and Kelley, S.: The Water Costs of Electricity in Arizona Arizona Department of Water Resources, Phoenix, AZ, 2008.

Perry, C. J.: Charging for irrigation water: The issues and options, with a case study from Iran, Research Report 52, International Water Management Institute, Colombo, Sri Lanka, 2001.

Pfister, S. and Hellweg, S.: The water "Shoesize" vs. Footprint of bioenergy, P. Natl. Acad. Sci., 106, E93-E94, 2009.

Pfister, S., Saner, D., and Koehler, A.: The environmental relevance of water consumption in global power production, Int. J Life Cycle Assess., 16, 580-591, doi:10.1007/s11367-011-02848, 2011.

Raynolds, M., Fraser, R., and Checkel, D.: The relative massenergy-economic (RMEE) method for system boundary selection Part 1: A means to systematically and quantitatively select LCA boundaries, Int. J. Life Cycle Assess., 5, 37-46, 2000.

Ridoutt, B. G. and Pfister, S.: A revised approach to water foot printing to make transparent the impacts of consumption and production on global freshwater scarcity, Global Environ. Change, 20, 113-120, 2010.

Sauterleute, J., Skarbøvik, E., Bakken, T. H., Egeland, H., Harby, A., Stålnacke, P. Nagothu, U. S., Palanisami, K., Krishna Reddy, K., and Gosain, K.: Application of the Building Block Methodology to the Sri Ram Sagar Project, SINTEF Report No. TR A7181, Trondheim, Norway, 44 pp., 2012.

Shiklomanov, I. A.: Appraisal and Assessment of World Water Resources, Water Int., 25, 11-32, doi:10.1080/02508060008686794, 2000.

Skarbøvik, E., Udnes, H., Øgaard, A., Eggestad, H., Rohrlack, T., Tingvold, J., and Drageseth, T.: Helhetlig utredning av manøvrering og flombegrensning i Vansjø, Integrated evaluation of dam operation and flood management of Lake Vansjø; in Norwegian, Bioforsk Rapport, 6, p. 60, 2011.

Solvang, E. Harby, A., and Killingtveit, Å.: Increasing balance power capacity in Norwegian hydroelectric power stations, SINTEF Report Serial No. TR A7195, SINTEF Energy Research, Trondheim, Norway, 2012.

Statkraft: Ulla-Førre Hydropower system, http://www.statkraft. no/energikilder/vannkraft/ulla-forreverkene.aspx, last access: 21 August 2013.

Tefferi, M.-E. A.: The effect of Ethiopian hydropower reservoirs on Blue Nile River flow regime, Master's thesis at Norwegian University of Science and Technology, Dept. of Hydraulic and Environmental Engineering, Norwegian University of Science and Technology, Trondheim, Norway, 2012.

Tharme, R. E. and King, J. M.: Development of the Building Block Methodology for instream flow assessments, and supporting research on the effects of different magnitude flows on riverine ecosystems, Water Research Commission Report No. 576/1/98, Water Research Commission, South Africa, p. 452, 1998.

Torcellini, P., Long, N., and Judkoff, R.: Consumptive Water Use for U.S. Power Production, Technical Report-TP-550-33905, National Renewable Energy Laboratory (NREL), Golden, CO, USA, 2003.

UNICEF and World Health Organization: Progress on drinking water and sanitation, 2012 Update, WHO/UNICEF Joint Monitoring Programme for Water Supply and Sanitation, Geneva, Switzerland, 2012. 
US Department of Energy: Energy demands on water resources, Report to Congress on the interdependency of energy and water, US Department of Energy, Washington, D.C., USA, p. 80, 2006.

US National Hydropower Association: http://www.hydro.org/ tech-and-policy/technology/small-hydro/, last access: $21 \mathrm{Au}-$ gust 2013.

van Steenbergen, F., Tuinhof, A., and Knoop, L.: Transforming lives, transforming landscapes. The business of sustainable water buffer management, 3R Water Secretariat, Wagenegen, the Netherlands, 2011.

Wörman, A., Lindström, G., Riml, J., and Åkesson, A.: Drifting runoff periodicity during the 20th century due to changing surface water volume, Hydrol. Process., 24, 3772-3784, doi:10.1002/hyp.7810, 2010.
Yesuf, M. B.: Impacts of Cascade Hydropower Plants on the flow of the River System and Water level in Lake Turkana in Omo-Ghibe Catchment, Ethiopia, Master's thesis at Norwegian University of Science and Technology, Dept. of Hydraulic and Environmental Engineering, Trondheim, Norway, 2012.

Yewhalaw, D., Legesse, W., Van Bortel, W., Gebre-Selassie, S., Kloos, H., Duchateau, L., and Speybroeck, N.: Malaria and water resource development: the case of Gilgel-Gibe hydroelectric dam in Ethiopia, Malaria J., 8, 21, doi:10.1186/1475-2875-8-21, 2009.

Zeng, Z., Liu, J., Koeneman, P. H., Zarate, E., and Hoekstra, A. Y.: Assessing water footprint at river basin level: a case study for the Heihe River Basin in northwest China, Hydrol. Earth Syst. Sci. 16, 2771-2781, doi:10.5194/hess-16-2771-2012, 2012. 